\title{
Rho GTPases in the Physiology and Pathophysiology of Peripheral Sensory Neurons
}

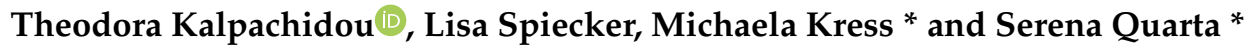 \\ Division of Physiology, Department of Physiology and Biomedical Physics, Medical University of Innsbruck, \\ 6020 Innsbruck, Austria; theodora.kalpachidou@i-med.ac.at (T.K.); lisa.spiecker@i-med.ac.at (L.S.) \\ * Correspondence: michaela.kress@i-med.ac.at (M.K.); sqserena.quarta@gmail.com (S.Q.)
}

Received: 22 May 2019; Accepted: 11 June 2019; Published: 15 June 2019

check for updates

\begin{abstract}
Numerous experimental studies demonstrate that the Ras homolog family of guanosine triphosphate hydrolases (Rho GTPases) Ras homolog family member A (RhoA), Ras-related C3 botulinum toxin substrate 1 (Rac1) and cell division cycle 42 (Cdc42) are important regulators in somatosensory neurons, where they elicit changes in the cellular cytoskeleton and are involved in diverse biological processes during development, differentiation, survival and regeneration. This review summarizes the status of research regarding the expression and the role of the Rho GTPases in peripheral sensory neurons and how these small proteins are involved in development and outgrowth of sensory neurons, as well as in neuronal regeneration after injury, inflammation and pain perception. In sensory neurons, Rho GTPases are activated by various extracellular signals through membrane receptors and elicit their action through a wide range of downstream effectors, such as Rho-associated protein kinase (ROCK), phosphoinositide 3-kinase (PI3K) or mixed-lineage kinase (MLK). While RhoA is implicated in the assembly of stress fibres and focal adhesions and inhibits neuronal outgrowth through growth cone collapse, Rac1 and Cdc42 promote neuronal development, differentiation and neuroregeneration. The functions of Rho GTPases are critically important in the peripheral somatosensory system; however, their signalling interconnections and partially antagonistic actions are not yet fully understood.
\end{abstract}

Keywords: Rho GTPases; actin cytoskeleton; sensory neurons; neurite outgrowth; neuroregeneration; development; inflammation; pain

\section{Introduction}

The members of the Ras homolog family of guanosine triphosphate hydrolases (Rho GTPases) are small GTP binding and hydrolysing proteins of approximately $21 \mathrm{kDa}$, which together with ADP ribosylation factors (Arfs), Ras-related proteins in brain (Rab), Ras-related nuclear protein (Ran) and Ras belong to the Ras superfamily of small GTPases [1]. In humans the Rho GTPase family has about 20 members that can be subdivided in to classic (typical) and atypical GTPases (Table 1) [2-4] and the most well studied today are Ras homolog family member A (RhoA), Ras-related C3 botulinum toxin substrate 1 (Rac1) and cell division cycle 42 [Cdc42 (Figure 1)].

The classic Rho GTPases hydrolyse GTP to GDP and thus cycle between the GTP bound active and the GDP bound inactive state [1]. The GTP/GDP cycling mechanism is finely tuned by Rho-specific guanine nucleotide exchange factors (GEFs), which promote the active state and GTPase activating proteins (GAPs), which favour the inactive state [5]. Additionally, the membrane localization of classic Rho GTPases affects their activity, and this is controlled by guanine nucleotide dissociation inhibitors (GDIs) [6]. In contrast, the atypical Rho GTPases are constantly bound to GTP, they do not hydrolyse GTP and there are no data supporting their regulation by GEFs or GAPs [3,7]. 
Table 1. The family of Rho GTPases, their members and expression in peripheral sensory neurons.

\begin{tabular}{|c|c|c|c|c|c|}
\hline \multicolumn{6}{|c|}{ Typical Rho GTPases } \\
\hline Subfamily & Members & $\begin{array}{l}\text { Expressed in peripheral } \\
\text { sensory neurons }\end{array}$ & Studied in PNI & $\begin{array}{l}\text { Expressed in other } \\
\text { neuronal cells }\end{array}$ & Reference \\
\hline \multirow{3}{*}{ Rho } & RhoA & Yes & Yes & Yes & [8] \\
\hline & RhoB & Yes & No & Yes & [8] \\
\hline & RhoC & Yes & No & Yes & [8] \\
\hline \multirow{4}{*}{ Rac } & Rac1 & Yes & Yes & Yes & [8] \\
\hline & Rac2 & Yes & No & Yes & [9] \\
\hline & Rac3 & Yes & No & Yes & [10] \\
\hline & RhoG & not documented & No & Yes & [11] \\
\hline \multirow{3}{*}{ Cdc42 } & Cdc42 & Yes & Yes & Yes & {$[8,12]$} \\
\hline & RhoQ (TC10) & Yes & No & Yes & {$[8]$} \\
\hline & RhoJ (TCL) & not documented & No & No & \\
\hline \multirow{2}{*}{ RhoF/RhoD } & RhoF (Rif) & not documented & No & Yes & [13] \\
\hline & RhoD & not documented & No & Yes & [14] \\
\hline \multicolumn{6}{|c|}{ Atypical Rho GTPases } \\
\hline Subfamily & Members & $\begin{array}{l}\text { Expressed in peripheral } \\
\text { sensory neurons }\end{array}$ & Studied in PNI & $\begin{array}{l}\text { Expressed in other } \\
\text { neuronal cells }\end{array}$ & Reference \\
\hline \multirow{3}{*}{ Rnd } & Rnd1 (RhoS) & not documented & No & Yes & [15] \\
\hline & Rnd2 (RhoN) & not documented & No & Yes & [16] \\
\hline & Rnd3 (RhoE) & not documented & No & Yes & [17] \\
\hline RhoBTB & $\begin{array}{l}\text { RhoBTB1 } \\
\text { RHoBTB2 }\end{array}$ & not documented & No & Yes & [18] \\
\hline $\mathrm{RhoH}$ & RhoH (TTF) & not documented & No & No & \\
\hline RhoU/RhoV & $\begin{array}{c}\text { RhoU (Wrch1) } \\
\text { RhoV (Chp/Wrch2) }\end{array}$ & not documented & No & Yes & [19] \\
\hline
\end{tabular}

PNI: peripheral nerve injury.

The cellular distribution of Rho GTPases indirectly regulates their function by restricting them to certain subcellular compartments. The intracellular localization of Rho GTPases is regulated by post-translational modifications (PTMs), such as isoprenylation $[20,21]$, which provides a membrane anchor or palmitoylation [22,23]. Moreover, the presence of a functional nuclear localization signal (NLS) sequence permits the correct nuclear entry and accumulation of these proteins [24]. Rho GTPase PTMs, such as phosphorylation, ubiquitylation and sumoylation, not only determine their localization but may also directly affect their function [25]. Various kinases, such as cAMP-dependent protein kinase A (PKA), cGMP-dependent protein kinase G (PKG), Src kinases and Akt, directly target and phosphorylate GTPases [25]. Phosphorylation changes the GTPase binding affinity to guanine nucleotides, promotes dissociation from the membrane and even induces degradation [25]. Ubiquitylation induces degradation of Rho GTPases [26], whereas Rac1 sumoylation increases Rho GTPase activity [27]. Additionally, different cytotoxins can either deactivate Rho GTPases via ADP-ribosylation, glucosylation, glucosaminylation and AMPylation or activate them via transglutamination [28]. Rho GTPase expression can be also regulated post-transcriptionally by microRNAs (miRNAs), such as miR-124 [29].

Rho GTPases can be activated by various extracellular signals acting on their respective receptors, such as G-protein coupled receptors (GPCRs) [30], receptors of the tyrosine kinase (RTKs) family [31], ionotropic receptors [32], plexins [33], integrins [34] and N-cadherin [35], which retain close proximity to GEFs and GAPs. These micro membrane-domains permit the linking of extracellular stimuli to Rho GTPase related signalling pathways (Figure 1). Upon activation, Rho GTPases act on their numerous downstream effectors, including among others serine/threonine kinases, such as Rho-associated protein kinase (ROCK) and protein kinase C-related kinase (PRK) for the Rho subfamily, p21-activated kinase (PAK) and mixed-lineage kinase (MLK) for the Rac subfamily and tyrosine kinases, such as activated Cdc42-associated tyrosine kinase (ACK) for the Cdc42 subfamily. Lipid kinases,-for example, Phosphoinositide 3-kinase (PI3K)-are downstream effectors for Rac and Cdc42 subfamilies 
and lipases, as well as scaffold proteins, such as diaphanous-related formin-1 (mDia), neutrophil cytosol factor 2 (p67phox) and Wiskott-Aldrich Syndrome protein (WASP) for Rho, Rac and Cdc42 subfamilies, respectively (for a review see Reference [36]).

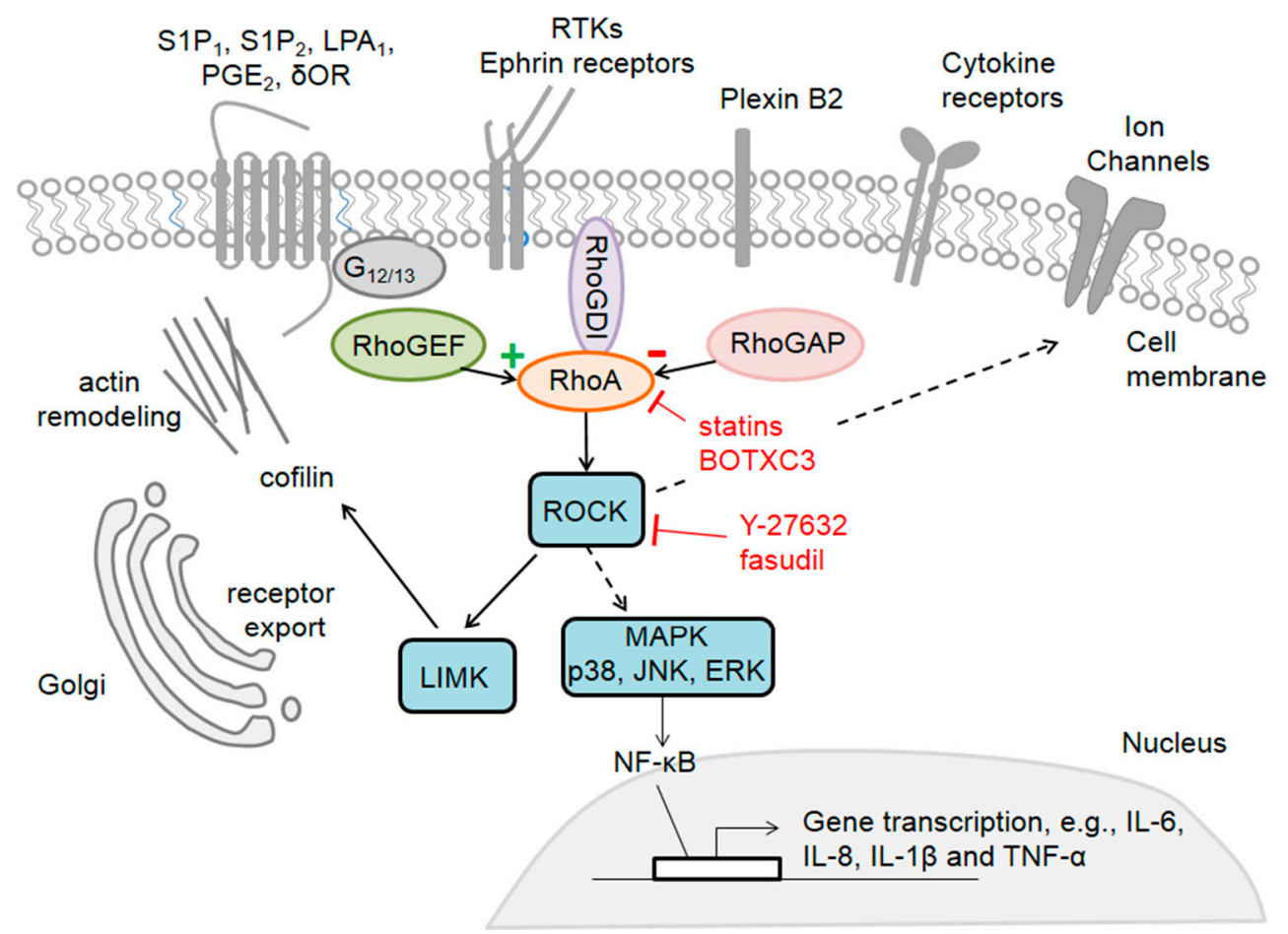

Figure 1. The family member RhoA, effectors and activators in sensory neurons. RhoA can be activated via different receptors, such as GPCRs (G-protein coupled receptors), RTKs (receptors of the tyrosine kinase family), cytokine receptors or ion channels. RhoA activity is regulated by specific proteins: GEFs (guanine nucleotide exchange factors) which promote its active state and GAPs (GTPase activating proteins) which turn it into an inactive state. By regulating various downstream effectors, RhoA elicits changes in the actin cytoskeleton and these effects can be pharmacologically modulated by inhibitors like Clostridium botulinum C3 toxin (BoTXC3) or fasudil.

Rho GTPases and in particular RhoA, Rac1 and Cdc42 have been identified and extensively studied as key regulators of actin cytoskeleton assembly and organization [37]. Specifically, RhoA activation promotes the assembly of stress fibres (actin-myosin filaments) and focal adhesions [38], Rac1 induces membrane ruffling and lamellipodia formation [39], whereas Cdc42 activation is responsible for the assembly of filopodia and actin microspikes [40]. Due to their role in actin cytoskeleton dynamics, Rho GTPases have been implicated in many cellular processes that depend on actin cytoskeleton remodelling, such as neuronal axon guidance, phagocytosis, cell migration, cell polarity and cell-cell interactions [41]. Besides microfilaments regulation, Rho GTPases are involved in gene expression and enzymatic activity and, in particular, RhoA, Rac1 and Cdc42 are associated with processes such as apoptosis, cell cycle, reactive oxygen species (ROS) production, membrane trafficking and proliferation [41]. Other processes that Rho GTPases are involved in are cell cycle progression [42], regulation of gene transcription [43] and neuronal morphology [44] as well as neuronal plasticity and migration [45]. As the multifaceted role of Rho GTPases became apparent, dysregulation of their activity was identified in multiple diseases and pathologies, including neurological [46] and neurodegenerative disorders [47,48], inflammation [49] and neuropathic pain [50,51].

In research, inhibitors of the activity of the different member of the Rho GTPases family have been used to understand their implication in all the above mentioned processes (Table 2). Although RhoA, Rac1 and Cdc42 have been identified as important regulators in a plethora of cellular functions in 
health and disease, the precise molecular pathways and signalling interconnections in the nervous system are complex and in particular in sensory neurons these pathways are not yet fully understood.

Table 2. The most commonly used inhibitors of Rho GTPases and downstream partners used in studies on peripheral sensory neurons.

\begin{tabular}{|c|c|c|c|}
\hline Inhibitor & Target & Role in Physiology & Role in Pathophysiology \\
\hline $\begin{array}{l}\text { statins } \\
\text { e.g., simvastatin }\end{array}$ & $\begin{array}{c}\text { prevents the } \\
\text { isoprenylation of Rho } \\
\text { GTPases }\end{array}$ & $\begin{array}{l}\text { Promoted neurogenesis and } \\
\text { migration of neural stem } \\
\text { cells [52] }\end{array}$ & $\begin{array}{l}\text { Attenuated pain behaviours after } \\
\text { PNI }[51,53,54]\end{array}$ \\
\hline BoTXC3 & $\begin{array}{l}\text { RhoA } \\
\text { RhoB } \\
\text { RhoC }\end{array}$ & & $\begin{array}{l}\text { Attenuated pain behaviours after PNI [50] } \\
\text { Promoted outgrowth of DRG [55-57] }\end{array}$ \\
\hline Y-27632 & ROCK & $\begin{array}{c}\text { Promoted neuronal } \\
\text { differentiation of iPSCs [58,59] } \\
\text { Promoted neurogenesis and } \\
\text { migration of neural stem } \\
\text { cells [52] }\end{array}$ & $\begin{array}{c}\text { Promoted DRG outgrowth in vitro [56] } \\
\text { Attenuated pain behaviours after } \\
\text { PNI }[33,50] \\
\text { Low doses mediated pro-nociceptive } \\
\text { responses [60] } \\
\text { High doses induced hypoalgesia and } \\
\text { reduced paw oedema [60] }\end{array}$ \\
\hline fasudil (HA-1077) & ROCK & $\begin{array}{l}\text { Increased neurite outgrowth of } \\
\text { GFR } \alpha 1 \text { DRG neurons in vitro } \\
\text { [61] }\end{array}$ & $\begin{array}{c}\text { Promoted DRG outgrowth in vitro [62] } \\
\text { Improved axonal regeneration after } \\
\text { PNI [62,63] } \\
\text { Low dose mediated pro-nociceptive } \\
\text { responses [60] } \\
\text { High doses induced hypoalgesia and } \\
\text { reduced paw oedema [60] }\end{array}$ \\
\hline
\end{tabular}

BoTXC3: Clostridium botulinum C3 toxin; DRG: dorsal root ganglia; GFR $\alpha 1$ : glial cell-derived neurotrophic factor coreceptor $\alpha 1$; iPSCs: induced pluripotent stem cells; PNI: peripheral nerve injury.

\section{Rho GTPases in Developing and Mature Sensory Neurons}

Within the Rho GTPase family, the most studied members in research addressing neuronal development are RhoA, Rac1 and Cdc42 (i.e., References [64-69]). They act as intracellular molecular switches that transduce signals from extracellular stimuli to the actin cytoskeleton and the nucleus. These Rho GTPases-associated signals regulate neuronal migration and morphogenesis, including processes, such as axonal polarization, axon growth and guidance, dendrite elaboration and plasticity as well as synapse formation.

Evidence for their importance in sensory neuron development, differentiation and survival is diverse and scattered through all sensory systems, such as cochlear hair cells [70,71], retinal photoreceptors [72] and somatosensory primary afferents including nociceptors [8,73,74]. Novel optogenetic and chemogenetic tools are increasingly available to experimentally target Rho GTPases and are extensively used in retinal and cochlear sensory neurons [75]. In this review we focus on primary somatosensory afferents, since Rho GTPases are recently receiving increasing attention as molecular switches setting the sensitivity to painful stimulation and as promising targets to improve peripheral nerve regeneration.

\subsection{Expression of Rho GTPases in Sensory Neurons}

Research on the role of Rho GTPases in sensory neurons started approximately 25 years ago in model systems as Caenorhabditis elegans and Drosophila melanogaster. Since the nervous system of C. elegans contains only 302 neurons, out of which sensory neurons account for about one-third [76], these animals are perfect models for basic neurobiological analysis. The role of RhoA in the sensory circuitry formation of C. elegans during post-embryonic development was described for the first time by W. Chen and L. Lim, who found that RhoA immunoreactivity in sensory neurons as well as in the nerve ring was high during larval development, suggesting a stage-specific role of RhoA in post-embryonic development [73]. 
In rodents, RhoA expression is particularly high in late embryonic stages and up to postnatal day 1 [74], while modest expression of RhoA mRNA persists during adult age. However, Rho GTPases levels are also profoundly upregulated after injury in sensory neurons found in dorsal root ganglia (DRG) [8], suggesting that Rho GTPases are involved in re- or degenerative processes (see below). Of the Rac type GTPases, Rac1 and Rac3 are expressed during embryonic development in the nervous system including proprioceptive and nociceptive neurons in the DRG [10,77]. Similarly, Cdc42 is expressed in DRG during development and adult age and upregulated following injury $[8,77]$.

\subsection{Rho GTPases in Sensory Neuron Development}

Rho GTPases are essential regulators of the cytoskeleton remodelling, which contributes to several aspects of neuronal development. Once a neuron is born it migrates a long way to find its final destination, where it starts to differentiate. It then sends out two types of processes: several dendrites to collect input and one axon to transport its output to its target cells. After establishing neuronal polarity, the axon navigates through a complex environment to find its destination and also dendrites grow and branch. Finally, synaptic connections to other neurons have to be established [78]. Accumulating evidence suggests that Rho GTPases act as key regulators in several of these processes. Most of the studies have been performed using human cell culture or genetically modified mouse lines. The different steps in neuronal development include specification, branching and elongation as well as retraction, navigation and guidance of axons (see e.g., References [79-82]), synaptic target side selection, growth and branching of dendrites plus formation and maturation of synapses (see e.g., References [48,83]).

Rho GTPases are involved in the regulation of polarization in different cell types, including neuronal cells. In 2008, Iden and Collard [84] proposed a crosstalk between Rho GTPases and polarity protein members of the partitioning defective (PAR) complex. In more detail, the emergence of a complex consisting of Cdc42, partitioning defective protein 6 (PAR6), PAR3, T cell lymphoma invasion and metastasis 1 (TIAM1) and Rac1 appears to be decisive in establishing neuronal polarity $[85,86]$.

Depletion of RhoA results in severe morphological deficits in the central nervous system (CNS) from embryonic day (E) 11.5, due to the early cell-cycle exit and precocious neuronal differentiation, suggesting an essential role for RhoA in the maintenance of spinal cord neuroepithelium organization and the neural stem cell pool [87]. However, despite the considerably high expression levels, depletion of RhoA from DRG neurons does not lead to major morphological deficits, such as disconnected axons from their target tissues, nor to functional deficits in proprioception or nociception, possibly due to compensatory upregulation of the other family member RhoC [74].

Conditional deletion of Rac1 in the ventricular zone results in neuronal migration deficits; it directs axon guidance, but it is not required for neuritogenesis [88]. In a conditional knock-out mouse, in which Rac1 is ablated in the whole brain, Rac1-deficient cerebellar granule neurons show impaired neuronal migration and axon formation both in vivo and in vitro. In addition, Rac1 ablation disrupts lamellipodia formation in growth cones and abolishes the expression of the WASP family verprolin-homologous protein (WAVE) complex from the plasma membrane of knock-out growth cones [89]. Neuronal death is observed in multiple locations, presumably as a secondary consequence of the axon growth and/or guidance defects. Following deletion of Rac1 in the forebrain, thalamocortical axons were misrouted inferiorly, with the majority projecting to the contralateral thalamus and a minority projecting ipsilaterally to the ventral cortex [90]. A reduction in the number of axons originating from the DRG and the sympathetic chain ganglia, dramatic reduction in the size of the DRG and number of DRG neurons in the brachial and thoracic regions was observed in embryos with a conditional depletion of Rac1, while the expression of DRG markers [brain-specific homeobox/POU domain protein 3A (Brn3a), insulin gene enhancer protein 1/2 (Islet1/2), sex determining region Y-box 10 (Sox10)] appeared unchanged [90]. DRG neurons were affected early in their development, since they were already missing from the sensory ganglia at E11.5 [90]. At present, it is not clear whether the primary defect occurs in neural crest migration, DRG axon growth and/or guidance or a combination 
of the two. In contrast, no major deficits of peripheral nerve system (PNS) development were observed after depletion of Rac3 [10].

Similar to the reports on RhoA and Rac1, Cdc42 is also involved in neuronal development including proliferation, initial dendritic development and dendritic spine maturation in the CNS [91]. Genetic ablation of Cdc42 in the brain leads to multiple abnormalities, including striking defects in the formation of axonal tracts, which is accompanied by disrupted cytoskeletal organization, enlargement of growth cones and inhibition of filopodial dynamics [92]. In addition, Cdc42 is indispensable for normal DRG development. At later stages than E10.5, Cdc42 conditional knock-out embryos have severe malformations, reminding the phenotype of Rac1 knock-out embryos and DRG are present but underdeveloped and reduced in size [93]. However, DRG cell differentiation seems to not be affected by the Cdc42 loss [93].

\subsection{Importance of Rho GTPases for Sensory Neuron Survival}

In general, Rac GTPases seem to have anti-apoptotic properties promoting neuronal survival acting on two signalling pathways: on one hand by activating the mitogen-activated protein kinase kinase 1/2 (MEK1/2)/extracellular signal-regulated kinase 1/2 (ERK1/2) signalling cascade, which represses the induction of the pro-apoptotic BH3-only protein Bim in an c-Jun N-terminal kinase (JNK)/c-Jun-dependent matter and on the other hand, by inhibiting the Janus kinase (JAK)/signal transducer and activator of transcription 5 (STAT5) signalling cascade that represses anti-apoptotic B-cell lymphoma-extra-large (Bcl-xL) [94-97]. Conversely, activation of RhoA and/or RhoB and downstream ROCK leads to neuronal apoptosis, which has been documented in different neurodegenerative models [98-100]. ROCK inhibitors (e.g. Y-27632) are therefore commonly used in protocols for neuronal differentiation from human induced pluripotent stem cells (iPSCs) to prevent apoptosis and increase survival after stem cell plating and after passaging of early neurons (Table 2) [58,59].

\section{Rho GTPases in Peripheral Nerve Injury}

Peripheral nerves contain sensory, motor and autonomic neurons, as well as non-neuronal cells, such as Schwann cells (SCs), other glial cells (e.g. satellite glial cells) and immune system cells (e.g., macrophages) [101]. Upon a peripheral nerve injury, non-neuronal cells initiate molecular and cellular processes termed Wallerian degeneration at the site of the injury, which together with resident immune cells promote clearing of cell debris and enhance conditions favouring axonal regeneration [102]. RhoA, Rac1 and Cdc42 have been found upregulated and activated in sensory neurons as well as non-neuronal cells following nerve lesion $[51,62,103,104]$. Therefore, in the following paragraphs we will focus on the role of Rho GTPases in sensory neuron responses to injury and address aspects of neuroregeneration, inflammation and neuropathic pain.

\subsection{Activation of Rho GTPases in Sensory Neurons After Injury}

The different members of the Rho GTPase family can be targeted by soluble factors as well as neighbouring cells to fine tune nerve regeneration after injury. The myelin-associated inhibitors Nogo, myelin-associated glycoprotein (MAG) and oligodendrocyte-myelin glycoprotein (OMgp) are well-known growth inhibitors, which cooperate with members of the Rho GTPases family. MAG is a potent inhibitor of neurite outgrowth localized in SCs. MAG binds both Nogo receptors (NgR), in particular the isoform 2 (NgR2) with high affinity [105]; however, in sensory neurons, deletion of $\mathrm{NgRs}$ does not affect the MAG-dependent neurite outgrowth inhibition [106]. Interestingly, the low-affinity neurotrophin receptor $\mathrm{p} 75^{\mathrm{NTR}}$ associates with $\mathrm{NgR}$ and acts as a signal transducer for MAG, Nogo and OMgp [107,108]. Activation of $\mathrm{p} 75^{\mathrm{NTR}}$ releases RhoA from RhoGDI and MAG promotes the association of RhoGDI to p75 ${ }^{\mathrm{NTR}}$, reducing the competitive binding of the RhoGEF Kalirin9 to $\mathrm{p} 75^{\mathrm{NTR}}$ [107]. These interactions cause the activation of RhoA/ROCK and subsequent growth cone collapse and inhibition of sensory axon growth. Moreover, Rho is directly activated by the myelin-associated inhibitor Nogo-66 [56]. Increased levels of active GTP-bound Rho are found in lysates of DRG neurons 
cultured on Nogo-66 and RhoA/ROCK inhibition promotes neurite outgrowth of sensory neurons in vitro [56].

Bioactive lipids, such as the sphingolipid sphingosine-1-phosphate (S1P) or lysophosphatidic acid (LPA, see below), bind different GPCRs and affect neuroregeneration. S1P 1 receptor associates with $\mathrm{G}_{\mathrm{i} / \mathrm{o}}$ to activate Rac1 and promotes migration and neurite outgrowth, whereas $\mathrm{S1P}_{2}$ and $\mathrm{S}_{1} \mathrm{P}_{3}$ receptors utilize $G_{12 / 13}$ to activate RhoA and ROCK, to induce growth cone collapse and inhibit migration $[57,109]$. An interesting partner, downstream of the RhoA/ROCK signalling, is the collapsin response mediator protein-2 (CRMP2) [110]. CRMP2 plays a role in embryonic development and neuronal polarity and is required for neurite elongation and axon formation [111-113]. It binds tubulin heterodimers and promotes microtubules assembly, however, when phosphorylated and inactivated, it inhibits tubulin polymerization and causes cytoskeleton destabilization [114]. ROCK-dependent phosphorylation/inactivation of CRMP2 mediates growth cone collapse and neurite retraction in DRG neurons $[57,115,116]$. In DRG neuronal cultures, RhoA and ROCK are activated by high doses of S1P through $\mathrm{S}_{1} \mathrm{P}_{3}$ receptor and mediate phosphorylation of CRMP2 at Thr-555. This post-transcriptional modification inactivates CRMP2 [57] and reduces neurite outgrowth in short-term cultures of both adult DRG neurons and motor neuron-like cells [57]. At very low doses S1P promotes elongation, rather than retraction, probably though $\mathrm{S}_{1} \mathrm{P}_{1}$ receptor and activation of Rac1 (Figure 2) [57]. In vivo, the lack of $\mathrm{S}_{1} \mathrm{P}_{3}$ receptors and the consequent RhoA signalling pathway destabilization, promotes functional recovery after peripheral nerve injury [57].

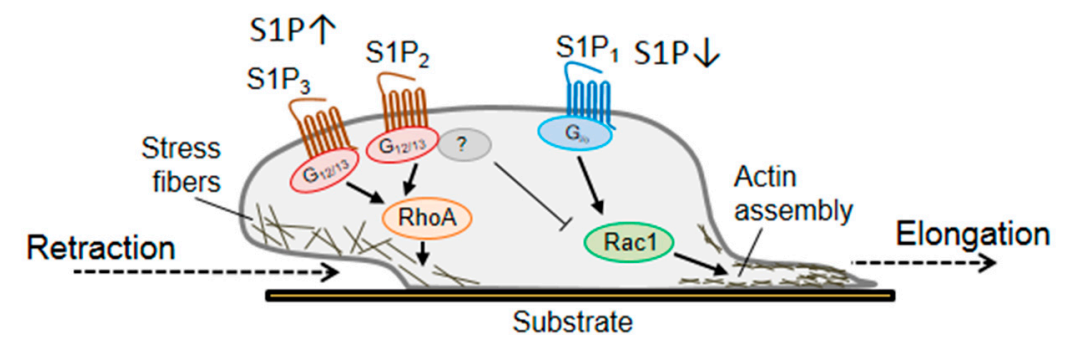

Figure 2. The sphingolipid S1P and the involvement of Rho GTPases in the outgrowth of sensory neurons. The bioactive lipid S1P elicits its action in sensory neurons depending on its local concentration and activates different members of the Rho GTPases family. High levels of S1P activate RhoA through the $\mathrm{S}_{\mathrm{P}} \mathrm{P}_{3}$ receptor and sensory neurons respond with a rapid retraction of neurites and growth cone collapse. On the other hand, $\mathrm{S}_{1} \mathrm{P}_{1}$ receptor seems to be associated with Rac1 activation and consequent elongation of neuronal processes.

\subsection{Rho GTPases in Peripheral Neuroregeneration and Neurite Outgrowth}

In contrast to neurons in the CNS, axons in the PNS possess the potential to regenerate. Rho GTPases regulate processes that are essential for the survival of neurons after injury and the subsequent target reinnervation. Dendritic arborization, spine formation, growth cone development and axon guidance are critically mediated by Rho GTPases. A tight spatial and temporal regulation of the Rho GTPases family members is crucial for proper neuronal morphology and nerve fibre regeneration after injury. This regulation is attributed to the spatio-temporal activation of GEFs and GAPs [117]. Additionally, antagonistic effects between the different members of the Rho GTPase family affect axon growth, axonal branching and growth cone formation, which are some of the most important processes of regeneration after injury [118]. Rac1/Cdc42 promote neuroregeneration, whereas Rho negatively affects actin dynamics, cellular shape and motility [41]. Despite the increased PNS plasticity and neuronal regeneration capacity, compared to CNS, functional reinnervation in adulthood by injured peripheral neurons is often difficult and not perfectly completed [41,88,119-121]. Immediately after injury, regenerating and uninjured axons compete to grow into the denervated tissue, such as the skin. In more advanced stages of regeneration, the capacity of the uninjured neurons to sprout and occupy the injured territories drastically diminishes. Studies on regeneration of trigeminal sensory 
axon terminals in live zebrafish larvae after axotomy showed that even regenerating injured axons might be repelled by the denervated skin at later stages of target reinnervation [121]. Interestingly, those regenerating axons are repelled by their former territories, where local inhibitory factors, like members of the $\mathrm{NgR} / \mathrm{RhoA}$ pathway, persist in their inhibitory function. Indeed, $\mathrm{NgR}$, its co-receptor leucine rich repeat and immunoglobin-like domain-containing protein 1 (LINGO-1), RhoA, ROCK and their intracellular partner CRMP2 might be partially required for the avoidance of these skin former territories and $\mathrm{O}^{\prime}$ Brien and colleagues demonstrated that antagonizing these factors improves the ability of injured axon to successfully reinnervate the skin after axotomy [121].

While RhoA elicits the assembly of actin stress fibres and focal adhesion and causes neurite retraction, Rac1 controls lamellipodia formation and membrane ruffles, through actin filament accumulation at the cell membrane, whereas Cdc42 stimulates filopodia formation and neurite outgrowth [117]. Dominant negative Rac1 in embryonic sensory neurons leads to axonal outgrowth defects without affecting dendrite growth, whereas Cdc42 mutations affect both axons and dendrites [122]. Mechanical tension appears closely linked to the development of neurites and defective neurite formation is observed in Rac1 deficient cells. The reason for this phenomenon seems to be a combination of compromised adhesion and motility in response to the lack of Rac1 (e.g., Reference [34]) and the organization of the actin cytoskeleton. Similar observations were described by Kozma et al. [44]. This and other studies in neuronal-like cells suggest that the fine balance between the outgrowth of neurites, the retraction of neurites and the increased activity of filopodium and/or lamellipodium at the growth cone might be regulated by the interplay between Rac1, Cdc42 and RhoA [44,123]. On the other hand, inhibition of RhoA by the recombinant membrane permeable Clostridium botulinum C3 toxin (BoTXC3) produces a minor but sufficient, outgrowth effect on the axon of peripheral sensory neurons after injury [55]. Small peptides obtained from BoTXC3 promote axon regeneration and motor recovery in both injured CNS and PNS [124,125]. However, direct neuronal overexpression of $\mathrm{C} 3$ transferase does not enhance axonal growth [55].

Growth and regeneration of sensory axons are also controlled via PI3K pathway, in which Akt regulates actin cytoskeleton via Rac1 and microtubules dynamics through the inactivation of glycogen synthase kinase 3 beta (GSK-3 $\beta$ ) [126,127]. Indeed, PI3K regulates various downstream partners that are important for axon polarity establishment and maintenance. PI3K is the so called symmetry-breaking signalling molecule and its activation guides the development of one of the neurites into an axon. Its overexpression enhances axon calibre and branching, likewise its inhibition was shown to inhibit axon formation [128-130]. Upon NGF stimulation, PI3K increases in fact Rac1 activity and transiently decreases RhoA signalling in the first stage of neurite outgrowth $[55,131]$. The PI3K-linked kinase p1108 is widely expressed in the PNS and its inactivation leads to an increased vulnerability of DRG neurons to growth cone collapse and decreased axon elongation [132]. In adult mice, loss of p1108 reduced axon regeneration and functional recovery after sciatic nerve injury and this impairment was associated with Akt signalling reduction and, noteworthy, RhoA activation [132]. Restoration of axonal extension in DRG neurons was achieved through pharmacological inhibition of the downstream signalling partner ROCK [56,62,132].

Moreover, the ROCK inhibitor fasudil increases axon numbers and improves axonal regeneration after sciatic nerve injury in vivo [62,63]. The response of sensory and motor nerves to peripheral nerve crush varies depending by the activation levels of RhoA and ROCK. In the presence of a non-permissive growth environment, sensory neurons cultured on chondroitin sulphate proteoglycans (CSPGs) were less responsive to the ROCK inhibitor Y-27632 compared to motor neurons [133]. These differences in response were associated to altered RhoA activation. In vivo, ROCK inhibition enhanced the regeneration of motor axons, whereas the growth of sensory fibres was not really affected [133]. Thus, the fine tuning of the RhoA/ROCK pathway may differently influence the capacity of sensory and motor neurons to regenerate. These discrepancies might be attributed either to the organism developmental stage or the cell type-specific regulation of Rho GTPase expression or, as mentioned above, the activation of specific receptors. 


\subsection{Rho GTPases in Neuroinflammation}

Most of the current literature highlights the role of RhoA on axonal regeneration and neuronal survival, however, there are several studies underlining the importance of Rho GTPases in SCs during regeneration. The Rho GTPases, in particular RhoA, regulate SCs differentiation, proliferation, migration and myelination mediated by the downstream JNK pathway and the p38 (MAPK) [134]. Interestingly, high levels of RhoA and Rac1 mRNA are found in SC derived exosomes, suggesting a role of these GTPases as cargo for intercellular signalling [135]. Cdc42 mRNA and protein levels increase significantly after sciatic nerve injury and a drastic reduction in Cdc42 mRNA expression inhibits SCs proliferation and migration $[12,136]$. Thus, SCs appear to support neuronal regeneration and proper target reinnervation through Rho GTPases. Furthermore, upon peripheral nerve injury, SCs, as well as resident and migrating immune cells, release pro-inflammatory mediators such as prostaglandins, reactive oxygen species (ROS), nitric oxide (NO), interleukins (IL) - $1 \beta$ (IL-1 $\beta$ ), IL-6, IL-8, IL-18, tumour necrosis factor $\alpha$ (TNF- $\alpha$ ) and leukaemia inhibitory factor (LIF), as well as anti-inflammatory cytokines, such as IL-10 and transforming growth factor $\beta 1$ (TGF- $\beta 1$ ) [137-139]. RhoA [140,141], Rac1 [142,143] and Cdc42 [141] activate in response to cytokines and lipopolysaccharide (LPS). Additionally, ROCK1 overexpression and LPS treatment promote inflammation and apoptosis via toll-like receptor 4 (TLR4) signalling, MAPKs (p38, ERK and JNK) activation, nuclear factor kappa-light-chain-enhancer of activated B cells (NF- $\mathrm{KB}$ ) activation and increased expression of IL-6, IL-8, IL-1 $\beta$ and TNF- $\alpha[144,145]$. The RhoA/ROCK pathway is commonly found upregulated in inflammatory processes and the inhibition of ROCK is usually associated with anti-inflammatory effects. Interestingly, in a rat model for inflammation, local application of low doses of the ROCK inhibitors Y-27632 and fasudil mediated pro-nociceptive responses, whereas high doses induced hypoalgesia and reduced paw oedemas [60]. Furthermore, the TNF- $\alpha$-Rac1-NF-kB axis activation induced the expression of matrix metalloproteinase 9 (MMP9) and inhibition of this signalling pathway resulted in anti-inflammatory effects [146]. In macrophages during nerve re-myelination in the area of the peripheral nerve injury, RhoA is activated via repulsive interactions between myelin, MAG, present on SCs and macrophage Nogo receptors 1 and 2 [104]. The activation of RhoA/ROCK reduces macrophage adhesion and enhances clearance from the site of inflammation through SC basal lamina, contributing to the termination of the inflammatory response [104].

\subsection{Rho GTPases and Nociception}

Due to their role in actin organization RhoA/ROCK affect ion channel and receptor membrane localization. Injection of complete Freunds' adjuvant into the paw induces sensitization of nociceptors to mechanical stimuli and mechanical hypersensitivity by modulating the function and membrane availability of transient receptor potential cation channel, subfamily A, member 1 (TRPA1). This process occurs through semaphorin 4C (Sema4C)/Plexin-B2/RhoA/ROCK signalling and the hypersensitivity was abolished by treatment with the ROCK inhibitor Y-27632 [33]. In the same model, heat-shock cognate 70 (Hsc70), a member of the heat shock protein (Hsp) chaperones, was found to promote the removal of the transient receptor potential vanilloid type 1 (TRPV1) from the cell membrane of DRG neurons by inhibiting the ROCK-dependent phosphorylation of TRPV1 [147].

Neuropathic pain is a consequence of nerve injury [148] and Rho GTPAses and their effectors have been implicated in the development and maintenance of neuropathic pain [50,51,149-154]. In this context the RhoA/ROCK pathway has been the most intensely studied and associated with aggravated behavioural and physiological responses in animal models of peripheral neuropathic pain, such as the partial sciatic nerve injury $[50,149,151]$, the chronic constriction injury (CCI) [39], the spared nerve injury (SNI) [152], the spinal nerve transection [153] and the spinal nerve ligation (SNL) [150,154]. The Rac1 subfamily of Rho GTPases seems to also be involved in neuropathic pain processes [150,155].

In addition to the aforementioned S1P, another bioactive lipid LPA is released by activated platelets after tissue injury and signals through GPCR receptors $\mathrm{LPA}_{1}, \mathrm{LPA}_{2}, \mathrm{LPA}_{3}$ and $\mathrm{LPA}_{4}$ [156]. Of particular interest in neuropathic pain research is the $\mathrm{LPA}_{1}$ receptor, which upon binding LPA 
or lysophosphatidylcholine (LPC) signals via $\mathrm{G} \alpha_{12 / 13}$ proteins and induces RhoA activation $[50,157]$. Additionally, LPA potentially via the RhoA/ROCK pathway promotes the demyelination of A-fibres in vivo and in ex vivo dorsal root fibre cultures $[50,158]$. The LPA-induced, as well as injury-induced allodynia, hyperalgesia and demyelination and voltage-gated calcium channel $\alpha 2 \delta 1$ subunit $\left(\mathrm{Ca}_{\alpha 2 \delta 1}\right)$ upregulation in the DRG, were abolished by either depleting the $\mathrm{LPA}_{1}$ receptor or by inhibition of RhoA or ROCK [50]. LPA- or nerve injury-induced pain is reduced by preventive inhibition of $\mathrm{LPA}_{1}$-RhoA-ROCK, suggesting that this signalling pathway is more important in the initiation but not maintenance of neuropathic pain [50]. The LPA-RhoA pathway has been found to upregulate 82 genes in DRG, including Ephrin B1 and calcium/calmodulin-dependent protein kinase II alpha (CAMKII $\alpha$ ), which may also contribute to this process [159]. In particular, ephrin receptors appear to play a role in neuropathic pain, since deletion of EphB2 in voltage-gated sodium ion channel 1.8-positive (Nav1.8+) nociceptive sensory neurons disrupted the increased thermal hyperalgesia and mechanical allodynia in mice subjected to a partial sciatic nerve injury [160].

Inhibition of Rho GTPase isoprenylation promotes anti-inflammatory and anti-nociceptive effects. Statins, such as simvastatin, are 3-Hydroxy-3-methylglutaryl coenzyme A (HMG-CoA) reductase inhibitors, which are commonly used for lowering cholesterol but also exert neuroprotective pleiotropic effects, including anti-inflammatory and anti-nociceptive actions [53]. Studies suggest that statins exhibit their effects by preventing the isoprenylation of Rho GTPases and thus inactivating them $[53,54]$. Simvastatin exhibited its effects on RhoA by retaining it inactive in the cytoplasm and this alleviated thermal hyperalgesia induced by experimental nerve injury [53,161]. Increased mechanical and thermal hypersensitivity are associated with increased RhoA membrane translocation, ROCK activation and subsequent LIM domain kinase (LIMK) and cofilin phosphorylation in isolectin B4 (IB4) and calcitonin gene-related peptide (CGRP) positive DRG neurons. Simvastatin attenuated pain behaviours and reduced RhoA membrane localization, thus inhibiting the ROCK/LIMK/cofilin pathway [51]. Similar effects are reported upon inhibition of either ROCK or cofilin phosphorylation [51]. Furthermore, the RhoA/ROCK/LIMK/cofilin signalling pathway has been implicated in the trafficking of delta opioid receptor ( $\delta \mathrm{OR}$ ) from the Golgi apparatus to the cell membrane of DRG neurons through a beta-arrestin 1 ( $\beta$-arr1)-dependent mechanism and it has been proposed that this pathway could be involved in the trafficking of other GPCRs, such as dopamine receptor 1 (DA1), neurotensin or protease-activated receptor 2 (PAR2) [162]. Although the DRG and primary afferent nociceptors are considered to be the initial station for the processing of painful stimuli, Rho GTPases and the underlying molecular interconnections are most relevant at the spinal dorsal horn level, which is not addressed in this review.

\section{Conclusions}

In sensory neurons and conditions related to neuronal development, differentiation, migration and regeneration, RhoA limits these processes and reduces regeneration through growth cone collapse and neurite retraction, while Rac1/Cdc42 promote a favourable environment for neuronal regeneration. Rho GTPases appear to be critically important for many processes following peripheral sensory neuron lesions and the signalling pathways they initiate and crosstalk with, are directly involved in inflammatory responses and neuropathic pain, indicating for example, that RhoA and its downstream effectors could serve as targets for therapeutic interventions. Although this review addressed all available information on the role of Rho GTPases in peripheral sensory neurons, the complexity and bidirectional interaction between inflammation and neuropathic pain in combination with the multidimensional roles of Rho GTPases and the lack of knowledge on the functions and interactions of most of the other members of the family in peripheral sensory neurons, necessitate further research in order to elucidate the molecular and physiological aspects, as well as the therapeutic potential, of these small intriguing proteins. Since activation of Rho GTPases occurs through numerous different mediators, revealing the nature of the complex signal through which Rho, Rac and Cdc42 fine tune growth cone extension and retraction may be difficult. Although the above studies and considerations indicate that Rho GTPases are remarkable targets of clinical importance, targeting upstream processes 
setting Rho GTPase activation tailored to the specific condition appears to be a more favourable strategy in order to add specificity and balance the activity of Rho GTPase signals under specific conditions.

Author Contributions: T.K., L.S., M.K. and S.Q. drafted the manuscript. All the authors added to and approved the final manuscript.

Funding: Supported by Austrian Science Fund (FWF): P286110.

Acknowledgments: Open Access Funding by the Austrian Science Fund (FWF): P286110.

Conflicts of Interest: The authors declare no conflict of interest.

\section{References}

1. Etienne-Manneville, S.; Hall, A. Rho gtpases in cell biology. Nature 2002. [CrossRef] [PubMed]

2. Cardama, G.A.; Gonzalez, N.; Maggio, J.; Menna, P.L.; Gomez, D.E. Rho gtpases as therapeutic targets in cancer (review). Int. J. Oncol. 2017, 51, 1025-1034. [CrossRef] [PubMed]

3. Haga, R.B.; Ridley, A.J. Rho gtpases: Regulation and roles in cancer cell biology. Small GTPases 2016, 7, 207-221. [CrossRef] [PubMed]

4. Olson, M.F. Rho gtpases, their post-translational modifications, disease-associated mutations and pharmacological inhibitors. Small GTPases 2016, 9, 203-215. [CrossRef] [PubMed]

5. Cherfils, J.; Zeghouf, M. Regulation of small gtpases by gefs, gaps, and gdis. Physiol. Rev. 2013, 93, $269-309$. [CrossRef] [PubMed]

6. Van Aelst, L.; D’Souza-Schorey, C. Rho gtpases and signaling networks. Genes Dev. 1997, 11, $2295-2322$. [CrossRef]

7. Lawson, C.D.; Ridley, A.J. Rho gtpase signaling complexes in cell migration and invasion. J. Cell Biol. 2018, 217, 447-457. [CrossRef] [PubMed]

8. Erschbamer, M.K.; Hofstetter, C.P.; Olson, L. Rhoa, rhob, rhoc, rac1, cdc42, and tc10 mrna levels in spinal cord, sensory ganglia, and corticospinal tract neurons and long-lasting specific changes following spinal cord injury. J. Comp. Neurol. 2005, 484, 224-233. [CrossRef]

9. $\mathrm{Wu}, \mathrm{X}$. Genome expression profiling predicts the molecular mechanism of peripheral myelination. Int. J. Mol. Med. 2018, 41, 1500-1508. [CrossRef]

10. Corbetta, S.; Gualdoni, S.; Albertinazzi, C.; Paris, S.; Croci, L.; Consalez, G.G.; de Curtis, I. Generation and characterization of rac3 knockout mice. Mol. Cell. Biol. 2005, 25, 5763-5776. [CrossRef]

11. Fujimoto, S.; Negishi, M.; Katoh, H. Rhog promotes neural progenitor cell proliferation in mouse cerebral cortex. Mol. Biol. Cell 2009, 20, 4941-4950. [CrossRef] [PubMed]

12. Han, B.; Zhao, J.Y.; Wang, W.T.; Li, Z.W.; He, A.P.; Song, X.Y. Cdc42 promotes schwann cell proliferation and migration through wnt/beta-catenin and p38 mapk signaling pathway after sciatic nerve injury. Neurochem. Res. 2017, 42, 1317-1324. [CrossRef] [PubMed]

13. Fan, L.; Yan, H.; Pellegrin, S.; Morigen; Mellor, H. The rif gtpase regulates cytoskeletal signaling from plexina4 to promote neurite retraction. Neurosci. Lett. 2015, 590, 178-183. [CrossRef] [PubMed]

14. Zanata, S.M.; Hovatta, I.; Rohm, B.; Puschel, A.W. Antagonistic effects of rnd1 and rhod gtpases regulate receptor activity in semaphorin 3a-induced cytoskeletal collapse. J. Neurosci 2002, 22, 471-477. [CrossRef] [PubMed]

15. Ishikawa, Y.; Katoh, H.; Negishi, M. A role of rnd1 gtpase in dendritic spine formation in hippocampal neurons. J. Neurosci 2003, 23, 11065-11072. [CrossRef]

16. Heng, J.I.; Nguyen, L.; Castro, D.S.; Zimmer, C.; Wildner, H.; Armant, O.; Skowronska-Krawczyk, D.; Bedogni, F.; Matter, J.M.; Hevner, R.; et al. Neurogenin 2 controls cortical neuron migration through regulation of rnd2. Nature 2008, 455, 114-118. [CrossRef]

17. Pacary, E.; Azzarelli, R.; Guillemot, F. Rnd3 coordinates early steps of cortical neurogenesis through actin-dependent and -independent mechanisms. Nat. Commun. 2013, 4, 1635. [CrossRef]

18. Ramos, S.; Khademi, F.; Somesh, B.P.; Rivero, F. Genomic organization and expression profile of the small gtpases of the rhobtb family in human and mouse. Gene 2002, 298, 147-157. [CrossRef]

19. Alan, J.K.; Robinson, S.K.; Magsig, K.L.; Demarco, R.S.; Lundquist, E.A. The atypical rho gtpase chw-1 works with sax-3/robo to mediate axon guidance in caenorhabditis elegans. G3 (Bethesda, Md.) 2018, 8, 1885-1895. [CrossRef] 
20. Mitin, N.; Roberts, P.J.; Chenette, E.J.; Der, C.J. Posttranslational lipid modification of rho family small gtpases. Methods Mol. Biol. 2012, 827, 87-95.

21. Roberts, P.J.; Mitin, N.; Keller, P.J.; Chenette, E.J.; Madigan, J.P.; Currin, R.O.; Cox, A.D.; Wilson, O.; Kirschmeier, P.; Der, C.J. Rho family gtpase modification and dependence on caax motif-signaled posttranslational modification. J. Biol. Chem. 2008, 283, 25150-25163. [CrossRef] [PubMed]

22. Navarro-Lérida, I.; Sánchez-Perales, S.; Calvo, M.; Rentero, C.; Zheng, Y.; Enrich, C.; Del Pozo, M.A. A palmitoylation switch mechanism regulates rac1 function and membrane organization. EMBO J. 2012, 31, 534-551. [CrossRef] [PubMed]

23. Pérez-Sala, D.; Boya, P.; Ramos, I.; Herrera, M.; Stamatakis, K. The c-terminal sequence of rhob directs protein degradation through an endo-lysosomal pathway. PLoS ONE 2009. [CrossRef] [PubMed]

24. Williams, C.L. The polybasic region of ras and rho family small gtpases: A regulator of protein interactions and membrane association and a site of nuclear localization signal sequences. Cell. Signalling 2003, 15, 1071-1080. [CrossRef]

25. Liu, M.; Bi, F.; Zhou, X.; Zheng, Y. Rho gtpase regulation by mirnas and covalent modifications. Trends Cell Biol. 2012, 22, 365-373. [CrossRef] [PubMed]

26. de la Vega, M.; Burrows, J.F.; Johnston, J.A. Ubiquitination: Added complexity in ras and rho family gtpase function. Small GTPases 2011, 2, 192-201. [CrossRef]

27. Castillo-Lluva, S.; Tatham, M.H.; Jones, R.C.; Jaffray, E.G.; Edmondson, R.D.; Hay, R.T.; Malliri, A. Sumoylation of the gtpase rac1 is required for optimal cell migration. Nat. Cell Biol. 2010, 12, 1078-1085. [CrossRef]

28. Visvikis, O.; Maddugoda, M.P.; Lemichez, E. Direct modifications of rho proteins: Deconstructing gtpase regulation. Biol. Cell 2010, 102, 377-389. [CrossRef]

29. Yu, J.-Y.; Chung, K.-H.; Deo, M.; Thompson, R.C.; Turner, D.L. Microrna mir-124 regulates neurite outgrowth during neuronal differentiation. Exp. Cell. Res. 2008, 314, 2618-2633. [CrossRef]

30. Bhattacharya, M.; Babwah, A.V.; Ferguson, S.S. Small gtp-binding protein-coupled receptors. Biochem. Soc. Trans. 2004, 32, 1040-1044. [CrossRef]

31. Schiller, M.R. Coupling receptor tyrosine kinases to rho gtpases-Gefs what's the link. Cell. Signalling 2006, 18, 1834-1843. [CrossRef] [PubMed]

32. Murakoshi, H.; Wang, H.; Yasuda, R. Local, persistent activation of rho gtpases during plasticity of single dendritic spines. Nature 2011, 472, 100-104. [CrossRef] [PubMed]

33. Paldy, E.; Simonetti, M.; Worzfeld, T.; Bali, K.K.; Vicuña, L.; Offermanns, S.; Kuner, R. Semaphorin 4c plexin-b2 signaling in peripheral sensory neurons is pronociceptive in a model of inflammatory pain. Nat. Commun. 2017, 8, 176. [CrossRef] [PubMed]

34. Hotchin, N.A.; Hall, A. The assembly of integrin adhesion complexes requires both extracellular matrix and intracellular rho/rac gtpases. J. Cell Biol. 1995, 131, 1857-1865. [CrossRef] [PubMed]

35. Charrasse, S.; Causeret, M.; Comunale, F.; Bonet-Kerrache, A.; Gauthier-Rouvière, C. Rho gtpases and cadherin-based cell adhesion in skeletal muscle development. J. Muscle Res. Cell Motil. 2003, 24, 311-315. [CrossRef]

36. Bishop, A.L.; Hall, A. Rho gtpases and their effector proteins. Biochem. J. 2000, 348, 241-255. [CrossRef] [PubMed]

37. Hall, A. Rho gtpases and the actin cytoskeleton. Science 1998, 279, 509-514. [CrossRef]

38. Ridley, A.J.; Hall, A. The small gtp-binding protein rho regulates the assembly of focal adhesions and actin stress fibers in response to growth factors. Cell 1992, 70, 389-399. [CrossRef]

39. Ridley, A.J.; Paterson, H.F.; Johnston, C.L.; Diekmann, D.; Hall, A. The small gtp-binding protein rac regulates growth factor-induced membrane ruffling. Cell 1992, 70, 401-410. [CrossRef]

40. Nobes, C.D.; Hall, A. Rho, rac, and cdc42 gtpases regulate the assembly of multimolecular focal complexes associated with actin stress fibers, lamellipodia, and filopodia. Cell 1995, 81, 53-62. [CrossRef]

41. Jaffe, A.B.; Hall, A. Rho gtpases: Biochemistry and biology. Annu. Rev. Cell Dev. Biol. 2005, 21, $247-269$. [CrossRef]

42. Olson, M.F.; Ashworth, A.; Hall, A. An essential role for rho, rac, and cdc42 gtpases in cell cycle progression through g1. Science 1995, 269, 1270-1272. [CrossRef] [PubMed]

43. Hill, C.S.; Wynne, J.; Treisman, R. The rho family gtpases rhoa, rac1, and cdc42hs regulate transcriptional activation by srf. Cell 1995, 81, 1159-1170. [CrossRef] 
44. Kozma, R.; Sarner, S.; Ahmed, S.; Lim, L. Rho family gtpases and neuronal growth cone remodelling: Relationship between increased complexity induced by cdc42hs, rac1, and acetylcholine and collapse induced by rhoa and lysophosphatidic acid. Mol. Cell. Biol. 1997, 17, 1201-1211. [CrossRef]

45. Sugihara, K.; Nakatsuji, N.; Nakamura, K.; Nakao, K.; Hashimoto, R.; Otani, H.; Sakagami, H.; Kondo, H.; Nozawa, S.; Aiba, A.; et al. Rac1 is required for the formation of three germ layers during gastrulation. Oncogene 1998, 17, 3427-3433. [CrossRef] [PubMed]

46. Nadif Kasri, N.; Van Aelst, L. Rho-linked genes and neurological disorders. Pflugers Arch. 2008, 455, 787-797. [CrossRef] [PubMed]

47. DeGeer, J.; Lamarche-Vane, N. Rho gtpases in neurodegeneration diseases. Exp. Cell Res. 2013, 319, $2384-2394$. [CrossRef] [PubMed]

48. Huang, G.H.; Sun, Z.L.; Li, H.J.; Feng, D.F. Rho gtpase-activating proteins: Regulators of rho gtpase activity in neuronal development and cns diseases. Molecul. Cell. Neurosci. 2017, 80, 18-31. [CrossRef] [PubMed]

49. Yu, O.M.; Brown, J.H. G protein-coupled receptor and rhoa-stimulated transcriptional responses: Links to inflammation, differentiation, and cell proliferation. Mol. Pharmacol. 2015, 88, 171-180. [CrossRef]

50. Inoue, M.; Rashid, M.H.; Fujita, R.; Contos, J.J.; Chun, J.; Ueda, H. Initiation of neuropathic pain requires lysophosphatidic acid receptor signaling. Nat. Med. 2004, 10, 712-718. [CrossRef]

51. Qiu, Y.; Chen, W.Y.; Wang, Z.Y.; Liu, F.; Wei, M.; Ma, C.; Huang, Y.G. Simvastatin attenuates neuropathic pain by inhibiting the rhoa/limk/cofilin pathway. Neurochem. Res. 2016, 41, 2457-2469. [CrossRef] [PubMed]

52. Zhang, C.; Wu, J.M.; Liao, M.; Wang, J.L.; Xu, C.J. The rock/ggtase pathway are essential to the proliferation and differentiation of neural stem cells mediated by simvastatin. J. Mol. Neurosci 2016, 60, 474-485. [CrossRef] [PubMed]

53. Cordle, A.; Koenigsknecht-Talboo, J.; Wilkinson, B.; Limpert, A.; Landreth, G. Mechanisms of statin-mediated inhibition of small g-protein function. J. Biol. Chem. 2005, 280, 34202-34209. [CrossRef] [PubMed]

54. Tristano, A.G.; Fuller, K. Immunomodulatory effects of statins and autoimmune rheumatic diseases: Novel intracellular mechanism involved. Int. Immunopharmacol. 2006, 6, 1833-1846. [CrossRef] [PubMed]

55. Auer, M.; Schweigreiter, R.; Hausott, B.; Thongrong, S.; Holtje, M.; Just, I.; Bandtlow, C.; Klimaschewski, L. Rho-independent stimulation of axon outgrowth and activation of the erk and akt signaling pathways by c3 transferase in sensory neurons. Front. Cell. Neurosci. 2012. [CrossRef] [PubMed]

56. Fournier, A.E.; Takizawa, B.T.; Strittmatter, S.M. Rho kinase inhibition enhances axonal regeneration in the injured cns. J. Neurosci 2003, 23, 1416-1423. [CrossRef]

57. Quarta, S.; Camprubi-Robles, M.; Schweigreiter, R.; Matusica, D.; Haberberger, R.V.; Proia, R.L.; Bandtlow, C.E.; Ferrer-Montiel, A.; Kress, M. Sphingosine-1-phosphate and the s1p3 receptor initiate neuronal retraction via rhoa/rock associated with crmp2 phosphorylation. Front. Mol. Neurosci. 2017, 10, 317. [CrossRef]

58. Chambers, S.M.; Qi, Y.; Mica, Y.; Lee, G.; Zhang, X.J.; Niu, L.; Bilsland, J.; Cao, L.; Stevens, E.; Whiting, P.; et al. Combined small-molecule inhibition accelerates developmental timing and converts human pluripotent stem cells into nociceptors. Nat. Biotech. 2012, 30, 715-720. [CrossRef]

59. Qi, Y.; Zhang, X.J.; Renier, N.; Wu, Z.; Atkin, T.; Sun, Z.; Ozair, M.Z.; Tchieu, J.; Zimmer, B.; Fattahi, F.; et al. Combined small-molecule inhibition accelerates the derivation of functional cortical neurons from human pluripotent stem cells. Nat. Biotechnol. 2017, 35, 154-163. [CrossRef]

60. Paiva-Lima, P.; Bakhle, Y.S.; Francischi, J.N. Dual effects of rho-kinase inhibitors on a rat model of inflammatory pain. Pain Res. Manag. 2014. [CrossRef]

61. Guo, G.; Singh, V.; Zochodne, D.W. Growth and turning properties of adult glial cell-derived neurotrophic factor coreceptor alpha1 nonpeptidergic sensory neurons. J. Neuropathol Exp. Neurol. 2014, 73, 820-836. [CrossRef] [PubMed]

62. Cheng, C.; Webber, C.A.; Wang, J.; Xu, Y.; Martinez, J.A.; Liu, W.Q.; McDonald, D.; Guo, G.F.; Nguyen, M.D.; Zochodne, D.W. Activated rhoa and peripheral axon regeneration. Exp. Neurol 2008, 212, 358-369. [CrossRef] [PubMed]

63. Hiraga, A.; Kuwabara, S.; Doya, H.; Kanai, K.; Fujitani, M.; Taniguchi, J.; Arai, K.; Mori, M.; Hattori, T.; Yamashita, T. Rho-kinase inhibition enhances axonal regeneration after peripheral nerve injury. J. Peripher. Nerv. Syst. 2006, 11, 217-224. [CrossRef] [PubMed]

64. Duman, J.G.; Mulherkar, S.; Tu, Y.K.; Cheng, J.X.; Tolias, K.F. Mechanisms for spatiotemporal regulation of rho-gtpase signaling at synapses. Neurosci. Lett. 2015, 601, 4-10. [CrossRef] [PubMed] 
65. Heasman, S.J.; Ridley, A.J. Mammalian rho gtpases: New insights into their functions from in vivo studies. Nat. Rev. Mol. Cell Biol. 2008, 9, 690-701. [CrossRef] [PubMed]

66. Miller, M.B.; Yan, Y.; Eipper, B.A.; Mains, R.E. Neuronal rho gefs in synaptic physiology and behavior. Neuroscientist 2013, 19, 255-273. [CrossRef] [PubMed]

67. Quinn, C.C.; Wadsworth, W.G. Axon guidance: Asymmetric signaling orients polarized outgrowth. Trends Cell Biol. 2008, 18, 597-603. [CrossRef]

68. Tolias, K.F.; Duman, J.G.; Um, K. Control of synapse development and plasticity by rho gtpase regulatory proteins. Prog. Neurobiol. 2011, 94, 133-148. [CrossRef]

69. Van Aelst, L.; Cline, H.T. Rho gtpases and activity-dependent dendrite development. Curr. Opin. Neurobiol. 2004, 14, 297-304. [CrossRef]

70. Kollmar, R. Who does the hair cell's 'do? Rho gtpases and hair-bundle morphogenesis. Curr. Opin. Neurobiol. 1999, 9, 394-398. [CrossRef]

71. Muller, U.; Littlewood-Evans, A. Mechanisms that regulate mechanosensory hair cell differentiation. Trends Cell Biol. 2001, 11, 334-342. [CrossRef]

72. Heynen, S.R.; Ogunshola, O.O.; Grimm, C. A brief account of rho gtpases in retinal physiology and pathophysiology. Adv. Exp. Med. Biol 2012, 723, 581-587. [PubMed]

73. Chen, W.; Lim, L. The caenorhabditis elegans small gtp-binding protein rhoa is enriched in the nerve ring and sensory neurons during larval development. J. Biol. Chem. 1994, 269, 32394-32404. [PubMed]

74. Leslie, J.R.; Imai, F.; Zhou, X.; Lang, R.A.; Zheng, Y.; Yoshida, Y. Rhoa is dispensable for axon guidance of sensory neurons in the mouse dorsal root ganglia. Front. Mol. Neurosci 2012, 5, 67. [CrossRef] [PubMed]

75. Beyer, H.M.; Naumann, S.; Weber, W.; Radziwill, G. Optogenetic control of signaling in mammalian cells. Biotechnol J. 2015, 10, 273-283. [CrossRef] [PubMed]

76. Ward, S.; Thomson, N.; White, J.G.; Brenner, S. Electron microscopical reconstruction of the anterior sensory anatomy of the nematode caenorhabditis elegans. J. Comp. Neurol. 1975, 160, 313-337. [CrossRef]

77. Terashima, T.; Yasuda, H.; Terada, M.; Kogawa, S.; Maeda, K.; Haneda, M.; Kashiwagi, A.; Kikkawa, R. Expression of rho-family gtpases (rac, cdc42, rhoa) and their association with p-21 activated kinase in adult rat peripheral nerve. J. Neurochem 2001, 77, 986-993. [CrossRef]

78. Luo, L. Rho gtpases in neuronal morphogenesis. Nat. Rev. Neurosci 2000, 1, 173-180. [CrossRef]

79. Kalil, K.; Dent, E.W. Branch management: Mechanisms of axon branching in the developing vertebrate cns. Nat. Rev. Neurosci. 2014, 15, 7-18. [CrossRef]

80. Raper, J.; Mason, C. Cellular strategies of axonal pathfinding. Cold Spring Harb. Perspect. Biol. 2010. [CrossRef]

81. Riccomagno, M.M.; Kolodkin, A.L. Sculpting neural circuits by axon and dendrite pruning. Annu. Rev. Cell Dev. Biol. 2015, 31, 779-805. [CrossRef] [PubMed]

82. Villarroel-Campos, D.; Bronfman, F.C.; Gonzalez-Billault, C. Rab gtpase signaling in neurite outgrowth and axon specification. Cytoskeleton 2016, 73, 498-507. [CrossRef] [PubMed]

83. Williams, M.E.; de Wit, J.; Ghosh, A. Molecular mechanisms of synaptic specificity in developing neural circuits. Neuron 2010, 68, 9-18. [CrossRef] [PubMed]

84. Iden, S.; Collard, J.G. Crosstalk between small gtpases and polarity proteins in cell polarization. Nat. Rev. Mol. Cell Biol. 2008, 9, 846-859. [CrossRef] [PubMed]

85. Nishimura, T.; Yamaguchi, T.; Kato, K.; Yoshizawa, M.; Nabeshima, Y.; Ohno, S.; Hoshino, M.; Kaibuchi, K. Par-6-par-3 mediates cdc42-induced rac activation through the rac gefs stef/tiam1. Nat. Cell Biol. 2005, 7, 270-277. [CrossRef]

86. Schwamborn, J.C.; Puschel, A.W. The sequential activity of the gtpases rap $1 \mathrm{~b}$ and cdc42 determines neuronal polarity. Nat. Neurosci. 2004, 7, 923-929. [CrossRef]

87. Herzog, D.; Loetscher, P.; van Hengel, J.; Knusel, S.; Brakebusch, C.; Taylor, V.; Suter, U.; Relvas, J.B. The small gtpase rhoa is required to maintain spinal cord neuroepithelium organization and the neural stem cell pool. J. Neurosci 2011, 31, 5120-5130. [CrossRef]

88. Chen, L.; Liao, G.; Waclaw, R.R.; Burns, K.A.; Linquist, D.; Campbell, K.; Zheng, Y.; Kuan, C.Y. Rac1 controls the formation of midline commissures and the competency of tangential migration in ventral telencephalic neurons. J. Neurosci 2007, 27, 3884-3893. [CrossRef] 
89. Tahirovic, S.; Hellal, F.; Neukirchen, D.; Hindges, R.; Garvalov, B.K.; Flynn, K.C.; Stradal, T.E.; Chrostek-Grashoff, A.; Brakebusch, C.; Bradke, F. Rac1 regulates neuronal polarization through the wave complex. J. Neurosci 2010, 30, 6930-6943. [CrossRef]

90. Hua, Z.L.; Emiliani, F.E.; Nathans, J. Rac1 plays an essential role in axon growth and guidance and in neuronal survival in the central and peripheral nervous systems. Neural Dev. 2015, 10, 21. [CrossRef]

91. Vadodaria, K.C.; Brakebusch, C.; Suter, U.; Jessberger, S. Stage-specific functions of the small rho gtpases cdc42 and rac1 for adult hippocampal neurogenesis. J. Neurosci 2013, 33, 1179-1189. [CrossRef] [PubMed]

92. Garvalov, B.K.; Flynn, K.C.; Neukirchen, D.; Meyn, L.; Teusch, N.; Wu, X.; Brakebusch, C.; Bamburg, J.R.; Bradke, F. Cdc42 regulates cofilin during the establishment of neuronal polarity. J. Neurosci. 2007, 27, 13117-13129. [CrossRef] [PubMed]

93. Fuchs, S.; Herzog, D.; Sumara, G.; Buchmann-Moller, S.; Civenni, G.; Wu, X.; Chrostek-Grashoff, A.; Suter, U.; Ricci, R.; Relvas, J.B.; et al. Stage-specific control of neural crest stem cell proliferation by the small rho gtpases cdc42 and rac1. Cell Stem Cell 2009, 4, 236-247. [CrossRef]

94. Le, S.S.; Loucks, F.A.; Udo, H.; Richardson-Burns, S.; Phelps, R.A.; Bouchard, R.J.; Barth, H.; Aktories, K.; Tyler, K.L.; Kandel, E.R.; et al. Inhibition of rac gtpase triggers a c-jun- and bim-dependent mitochondrial apoptotic cascade in cerebellar granule neurons. J. Neurochem. 2005, 94, 1025-1039. [CrossRef] [PubMed]

95. Linseman, D.A.; Laessig, T.; Meintzer, M.K.; McClure, M.; Barth, H.; Aktories, K.; Heidenreich, K.A. An essential role for rac/cdc42 gtpases in cerebellar granule neuron survival. J. Biol Chem. 2001, 276, 39123-39131. [CrossRef] [PubMed]

96. Loucks, F.A.; Le, S.S.; Zimmermann, A.K.; Ryan, K.R.; Barth, H.; Aktories, K.; Linseman, D.A. Rho family gtpase inhibition reveals opposing effects of mitogen-activated protein kinase kinase/extracellular signal-regulated kinase and janus kinase/signal transducer and activator of transcription signaling cascades on neuronal survival. J. Neurochem. 2006, 97, 957-967. [CrossRef]

97. Stankiewicz, T.R.; Loucks, F.A.; Schroeder, E.K.; Nevalainen, M.T.; Tyler, K.L.; Aktories, K.; Bouchard, R.J.; Linseman, D.A. Signal transducer and activator of transcription- 5 mediates neuronal apoptosis induced by inhibition of rac gtpase activity. J. Biol. Chem. 2012, 287, 16835-16848. [CrossRef]

98. Barberan, S.; McNair, K.; Iqbal, K.; Smith, N.C.; Prendergast, G.C.; Stone, T.W.; Cobb, S.R.; Morris, B.J. Altered apoptotic responses in neurons lacking rhob gtpase. Eur. J. Neurosci. 2011, 34, 1737-1746. [CrossRef]

99. Semenova, M.M.; Maki-Hokkonen, A.M.; Cao, J.; Komarovski, V.; Forsberg, K.M.; Koistinaho, M.; Coffey, E.T.; Courtney, M.J. Rho mediates calcium-dependent activation of p38alpha and subsequent excitotoxic cell death. Nat. Neurosci. 2007, 10, 436-443. [CrossRef]

100. Zhang, Y.; Zhao, J.; Wang, J.; Jiao, X. Brain-derived neurotrophic factor inhibits phenylalanine-induced neuronal apoptosis by preventing rhoa pathway activation. Neurochem. Res. 2010, 35, 480-486. [CrossRef]

101. Menorca, R.M.G.; Fussell, T.S.; Elfar, J.C. Nerve physiology: Mechanisms of injury and recovery. Hand Clin. 2013, 29, 317-330. [CrossRef] [PubMed]

102. Rotshenker, S. Wallerian degeneration: The innate-immune response to traumatic nerve injury. J. Neuroinflammation 2011. [CrossRef] [PubMed]

103. Abrams, M.; Widenfalk, J. Emerging strategies to promote improved functional outcome after peripheral nerve injury. Restor. Neurol. Neurosci. 2005, 23, 367-382. [PubMed]

104. Fry, E.J.; Ho, C.; David, S. A role for nogo receptor in macrophage clearance from injured peripheral nerve. Neuron 2007, 53, 649-662. [CrossRef] [PubMed]

105. Venkatesh, K.; Chivatakarn, O.; Lee, H.; Joshi, P.S.; Kantor, D.B.; Newman, B.A.; Mage, R.; Rader, C.; Giger, R.J The nogo-66 receptor homolog ngr2 is a sialic acid-dependent receptor selective for myelin-associated glycoprotein. J. Neurosci 2005, 25, 808-822. [CrossRef] [PubMed]

106. Worter, V.; Schweigreiter, R.; Kinzel, B.; Mueller, M.; Barske, C.; Bock, G.; Frentzel, S.; Bandtlow, C.E. Inhibitory activity of myelin-associated glycoprotein on sensory neurons is largely independent of ngr1 and ngr2 and resides within ig-like domains 4 and 5. PLoS ONE 2009. [CrossRef] [PubMed]

107. Harrington, A.W.; Li, Q.M.; Tep, C.; Park, J.B.; He, Z.; Yoon, S.O. The role of kalirin9 in p75/nogo receptor-mediated rhoa activation in cerebellar granule neurons. J. Biol. Chem. 2008, 283, 24690-24697. [CrossRef] [PubMed]

108. Yamashita, T.; Higuchi, H.; Tohyama, M. The p75 receptor transduces the signal from myelin-associated glycoprotein to rho. J. Cell Biol. 2002, 157, 565-570. [CrossRef] 
109. Brinkmann, V. Sphingosine 1-phosphate receptors in health and disease: Mechanistic insights from gene deletion studies and reverse pharmacology. Pharmacol. Ther. 2007, 115, 84-105. [CrossRef] [PubMed]

110. Mimura, F.; Yamagishi, S.; Arimura, N.; Fujitani, M.; Kubo, T.; Kaibuchi, K.; Yamashita, T. Myelin-associated glycoprotein inhibits microtubule assembly by a rho-kinase-dependent mechanism. J. Biol. Chem. 2006, 281, 15970-15979. [CrossRef] [PubMed]

111. Arimura, N.; Menager, C.; Fukata, Y.; Kaibuchi, K. Role of crmp-2 in neuronal polarity. J. Neurobiol 2004, 58, 34-47. [CrossRef] [PubMed]

112. Inagaki, N.; Chihara, K.; Arimura, N.; Menager, C.; Kawano, Y.; Matsuo, N.; Nishimura, T.; Amano, M.; Kaibuchi, K. Crmp-2 induces axons in cultured hippocampal neurons. Nat. Neurosci 2001, 4, 781-782. [CrossRef] [PubMed]

113. Wang, L.H.; Strittmatter, S.M. A family of rat crmp genes is differentially expressed in the nervous system. J. Neurosci 1996, 16, 6197-6207. [CrossRef] [PubMed]

114. Fukata, Y.; Itoh, T.J.; Kimura, T.; Menager, C.; Nishimura, T.; Shiromizu, T.; Watanabe, H.; Inagaki, N.; Iwamatsu, A.; Hotani, H.; et al. Crmp-2 binds to tubulin heterodimers to promote microtubule assembly. Nat. Cell Biol. 2002, 4, 583-591. [CrossRef] [PubMed]

115. Arimura, N.; Inagaki, N.; Chihara, K.; Menager, C.; Nakamura, N.; Amano, M.; Iwamatsu, A.; Goshima, Y.; Kaibuchi, K. Phosphorylation of collapsin response mediator protein-2 by rho-kinase. Evidence for two separate signaling pathways for growth cone collapse. J. Biol. Chem 2000, 275, 23973-23980. [CrossRef] [PubMed]

116. Arimura, N.; Menager, C.; Kawano, Y.; Yoshimura, T.; Kawabata, S.; Hattori, A.; Fukata, Y.; Amano, M.; Goshima, Y.; Inagaki, M.; et al. Phosphorylation by rho kinase regulates crmp-2 activity in growth cones. Mol. Cell Biol. 2005, 25, 9973-9984. [CrossRef]

117. da Silva, J.S.; Dotti, C.G. Breaking the neuronal sphere: Regulation of the actin cytoskeleton in neuritogenesis. Nat. Rev. Neurosci. 2002, 3, 694-704. [CrossRef]

118. Bradke, F.; Dotti, C.G. The role of local actin instability in axon formation. Science 1999, 283, $1931-1934$. [CrossRef]

119. Hoke, A. Mechanisms of disease: What factors limit the success of peripheral nerve regeneration in humans? Nat. Clin. Pract. Neurol. 2006, 2, 448-454. [CrossRef]

120. Navarro, X.; Verdu, E.; Wendelschafer-Crabb, G.; Kennedy, W.R. Immunohistochemical study of skin reinnervation by regenerative axons. J. Comp. Neurol. 1997, 380, 164-174. [CrossRef]

121. O’Brien, G.S.; Martin, S.M.; Sollner, C.; Wright, G.J.; Becker, C.G.; Portera-Cailliau, C.; Sagasti, A. Developmentally regulated impediments to skin reinnervation by injured peripheral sensory axon terminals. Curr. Biol. 2009, 19, 2086-2090. [CrossRef] [PubMed]

122. Luo, L.; Liao, Y.J.; Jan, L.Y.; Jan, Y.N. Distinct morphogenetic functions of similar small gtpases: Drosophila drac1 is involved in axonal outgrowth and myoblast fusion. Genes Dev. 1994, 8, 1787-1802. [CrossRef] [PubMed]

123. Jalink, K.; van Corven, E.J.; Hengeveld, T.; Morii, N.; Narumiya, S.; Moolenaar, W.H. Inhibition of lysophosphatidate- and thrombin-induced neurite retraction and neuronal cell rounding by adp ribosylation of the small gtp-binding protein rho. J. Cell Biol. 1994, 126, 801-810. [CrossRef] [PubMed]

124. Boato, F.; Hendrix, S.; Huelsenbeck, S.C.; Hofmann, F.; Grosse, G.; Djalali, S.; Klimaschewski, L.; Auer, M.; Just, I.; Ahnert-Hilger, G.; et al. C3 peptide enhances recovery from spinal cord injury by improved regenerative growth of descending fiber tracts. J. Cell Sci. 2010, 123, 1652-1662. [CrossRef] [PubMed]

125. Huelsenbeck, S.C.; Rohrbeck, A.; Handreck, A.; Hellmich, G.; Kiaei, E.; Roettinger, I.; Grothe, C.; Just, I.; Haastert-Talini, K. C3 peptide promotes axonal regeneration and functional motor recovery after peripheral nerve injury. Neurotherapeutics 2012, 9, 185-198. [CrossRef] [PubMed]

126. Yoshimura, T.; Kawano, Y.; Arimura, N.; Kawabata, S.; Kikuchi, A.; Kaibuchi, K. Gsk-3beta regulates phosphorylation of crmp-2 and neuronal polarity. Cell 2005, 120, 137-149. [CrossRef]

127. Zhou, F.Q.; Zhou, J.; Dedhar, S.; Wu, Y.H.; Snider, W.D. Ngf-induced axon growth is mediated by localized inactivation of gsk-3beta and functions of the microtubule plus end binding protein apc. Neuron 2004, 42, 897-912. [CrossRef]

128. Shi, S.H.; Jan, L.Y.; Jan, Y.N. Hippocampal neuronal polarity specified by spatially localized mpar3/mpar6 and pi 3-kinase activity. Cell 2003, 112, 63-75. [CrossRef]

129. Tahirovic, S.; Bradke, F. Neuronal polarity. Cold Spring Harb. Perspect. Biol. 2009. [CrossRef] 
130. Kim, Y.T.; Hur, E.M.; Snider, W.D.; Zhou, F.Q. Role of gsk3 signaling in neuronal morphogenesis. Front. Mol. Neurosci. 2011, 4, 48. [CrossRef]

131. Nusser, N.; Gosmanova, E.; Zheng, Y.; Tigyi, G. Nerve growth factor signals through trka, phosphatidylinositol 3-kinase, and rac1 to inactivate rhoa during the initiation of neuronal differentiation of pc12 cells. J. Biol. Chem. 2002, 277, 35840-35846. [CrossRef] [PubMed]

132. Eickholt, B.J.; Ahmed, A.I.; Davies, M.; Papakonstanti, E.A.; Pearce, W.; Starkey, M.L.; Bilancio, A.; Need, A.C.; Smith, A.J.; Hall, S.M.; et al. Control of axonal growth and regeneration of sensory neurons by the p110delta PI 3-kinase. PLoS ONE 2007. [CrossRef] [PubMed]

133. Joshi, A.R.; Bobylev, I.; Zhang, G.; Sheikh, K.A.; Lehmann, H.C. Inhibition of rho-kinase differentially affects axon regeneration of peripheral motor and sensory nerves. Exp. Neurol. 2015, 263, 28-38. [CrossRef] [PubMed]

134. Wen, J.; Tan, D.; Li, L.; Wang, X.; Pan, M.; Guo, J. Rhoa regulates schwann cell differentiation through jnk pathway. Exp. Neurol. 2018, 308, 26-34. [CrossRef] [PubMed]

135. Ching, R.C.; Wiberg, M.; Kingham, P.J. Schwann cell-like differentiated adipose stem cells promote neurite outgrowth via secreted exosomes and rna transfer. Stem Cell Res. Ther. 2018, 9, 266. [CrossRef] [PubMed]

136. Pasten, C.; Cerda, J.; Jausoro, I.; Court, F.A.; Cáceres, A.; Marzolo, M.-P. Apoer2 and reelin are expressed in regenerating peripheral nerve and regulate schwann cell migration by activating the rac1 gef protein, tiam1. Mol. Cell. Neurosci. 2015, 69, 1-11. [CrossRef]

137. Ji, R.-R.; Chamessian, A.; Zhang, Y.-Q. Pain regulation by non-neuronal cells and inflammation. Science 2016, 354, 572-577. [CrossRef]

138. Ji, R.-R.; Xu, Z.-Z.; Gao, Y.-J. Emerging targets in neuroinflammation-driven chronic pain. Nat. Rev. Drug Discov. 2014. [CrossRef]

139. Scholz, J.; Woolf, C.J. The neuropathic pain triad: Neurons, immune cells and glia. Nat. Neurosci. 2007, 10, 1361. [CrossRef]

140. Neumann, H.; Schweigreiter, R.; Yamashita, T.; Rosenkranz, K.; Wekerle, H.; Barde, Y.A. Tumor necrosis factor inhibits neurite outgrowth and branching of hippocampal neurons by a rho-dependent mechanism. J. Neurosci. 2002, 22, 854-862. [CrossRef]

141. Perona, R.; Montaner, S.; Saniger, L.; Sanchez-Perez, I.; Bravo, R.; Lacal, J.C. Activation of the nuclear factor-kappab by rho, cdc42, and rac-1 proteins. Genes Dev. 1997, 11, 463-475. [CrossRef] [PubMed]

142. Reddig, P.J.; Xu, D.; Juliano, R.L. Regulation of p21-activated kinase-independent rac1 signal transduction by nischarin. J. Biol. Chem. 2005, 280, 30994-31002. [CrossRef] [PubMed]

143. Tzima, E.; Del Pozo, M.A.; Kiosses, W.B.; Mohamed, S.A.; Li, S.; Chien, S.; Schwartz, M.A. Activation of rac1 by shear stress in endothelial cells mediates both cytoskeletal reorganization and effects on gene expression. EMBO J. 2002, 21, 6791-6800. [CrossRef] [PubMed]

144. Gong, J.; Guan, L.; Tian, P.; Li, C.; Zhang, Y. Rho kinase type 1 (rock1) promotes lipopolysaccharide-induced inflammation in corneal epithelial cells by activating toll-like receptor 4 (tlr4)-mediated signaling. Med. Sci. Monit. 2018, 24, 3514-3523. [CrossRef]

145. Wang, Q.; Cheng, F.; Xu, Y.; Zhang, J.; Qi, J.; Liu, X.; Wang, R. Thymol alleviates lipopolysaccharide-stimulated inflammatory response via downregulation of rhoa-mediated nf-kappab signalling pathway in human peritoneal mesothelial cells. Eur. J. Pharmacol. 2018, 833, 210-220. [CrossRef] [PubMed]

146. Balasubramanian, S.; Fan, M.; Messmer-Blust, A.F.; Yang, C.H.; Trendel, J.A.; Jeyaratnam, J.A.; Pfeffer, L.M.; Vestal, D.J. The interferon-gamma-induced gtpase, mgbp-2, inhibits tumor necrosis factor alpha (tnf-alpha) induction of matrix metalloproteinase-9 (mmp-9) by inhibiting nf-kappab and rac protein. J. Biol. Chem. 2011, 286, 20054-20064. [CrossRef] [PubMed]

147. Iftinca, M.; Flynn, R.; Basso, L.; Melo, H.; Aboushousha, R.; Taylor, L.; Altier, C. The stress protein heat shock cognate 70 (hsc70) inhibits the transient receptor potential vanilloid type 1 (trpv1) channel. Mol. Pain 2016, 12, 1744806916663945. [CrossRef]

148. van Hecke, O.; Austin, S.K.; Khan, R.A.; Smith, B.H.; Torrance, N. Neuropathic pain in the general population: A systematic review of epidemiological studies. Pain 2014, 155, 654-662. [CrossRef]

149. Inoue, M.; Yamaguchi, A.; Kawakami, M.; Chun, J.; Ueda, H. Loss of spinal substance p pain transmission under the condition of lpa1 receptor-mediated neuropathic pain. Mol. Pain 2006, 2, 25. [CrossRef] 
150. Li, N.; Li, C.; Han, R.; Wang, Y.; Yang, M.; Wang, H.; Tian, J. Lpm580098, a novel triple reuptake inhibitor of serotonin, noradrenaline, and dopamine, attenuates neuropathic pain. Front. Pharmacol. 2019, 10, 53. [CrossRef]

151. Ohsawa, M.; Ishikura, K.-I.; Mutoh, J.; Hisa, H. Involvement of inhibition of rhoa/rho kinase signaling in simvastatin-induced amelioration of neuropathic pain. Neuroscience 2016, 333, 204-213. [CrossRef] [PubMed]

152. Tatsumi, E.; Yamanaka, H.; Kobayashi, K.; Yagi, H.; Sakagami, M.; Noguchi, K. Rhoa/rock pathway mediates p38 mapk activation and morphological changes downstream of p2y12/13 receptors in spinal microglia in neuropathic pain. Glia 2015, 63, 216-228. [CrossRef] [PubMed]

153. Tatsumi, S.; Mabuchi, T.; Katano, T.; Matsumura, S.; Abe, T.; Hidaka, H.; Suzuki, M.; Sasaki, Y.; Minami, T.; Ito, S. Involvement of rho-kinase in inflammatory and neuropathic pain through phosphorylation of myristoylated alanine-rich c-kinase substrate (marcks). Neuroscience 2005, 131, 491-498. [CrossRef] [PubMed]

154. Yu, T.; Zhang, X.; Shi, H.; Tian, J.; Sun, L.; Hu, X.; Cui, W.; Du, D. P2y12 regulates microglia activation and excitatory synaptic transmission in spinal lamina ii neurons during neuropathic pain in rodents. Cell Death Dis. 2019. [CrossRef] [PubMed]

155. Tan, A.M.; Chang, Y.-W.; Zhao, P.; Hains, B.C.; Waxman, S.G. Rac1-regulated dendritic spine remodeling contributes to neuropathic pain after peripheral nerve injury. Exp. Neurol. 2011, 232, 222-233. [CrossRef]

156. Ishii, I.; Fukushima, N.; Ye, X.; Chun, J. Lysophospholipid receptors: Signaling and biology. Annu. Rev. Biochem. 2004, 73, 321-354. [CrossRef]

157. Inoue, M.; Xie, W.; Matsushita, Y.; Chun, J.; Aoki, J.; Ueda, H. Lysophosphatidylcholine induces neuropathic pain through an action of autotaxin to generate lysophosphatidic acid. Neuroscience 2008, 152, 296-298. [CrossRef]

158. Fujita, R.; Kiguchi, N.; Ueda, H. Lpa-mediated demyelination in ex vivo culture of dorsal root. Neurochem. Int. 2007, 50, 351-355. [CrossRef]

159. Uchida, H.; Matsumoto, M.; Ueda, H. Profiling of bont/c3-reversible gene expression induced by lysophosphatidic acid: Ephrinb1 gene up-regulation underlying neuropathic hyperalgesia and allodynia. Neurochem. Int. 2009, 54, 215-221. [CrossRef]

160. Zhao, J.; Yuan, G.; Cendan, C.M.; Nassar, M.A.; Lagerstrom, M.C.; Kullander, K.; Gavazzi, I.; Wood, J.N. Nociceptor-expressed ephrin-b2 regulates inflammatory and neuropathic pain. Mol. Pain 2010, 6, 77. [CrossRef]

161. Ohsawa, M.; Mutoh, J.; Yamamoto, S.; Hisa, H. Involvement of protein isoprenylation in neuropathic pain induced by sciatic nerve injury in mice. Neurosci. Lett. 2014, 564, 27-31. [CrossRef] [PubMed]

162. Mittal, N.; Roberts, K.; Pal, K.; Bentolila, L.A.; Fultz, E.; Minasyan, A.; Cahill, C.; Pradhan, A.; Conner, D.; DeFea, K.; et al. Select g-protein-coupled receptors modulate agonist-induced signaling via a rock, limk, and $\beta$-arrestin 1 pathway. Cell Rep. 2013, 5, 1010-1021. [CrossRef] [PubMed] 